\title{
Memorial Architecture as the Symbol of Remembrance and Memories
}

\author{
Danijela Miodrag Dimković \\ Faculty of Philology and Arts, University of Kragujevac, Kragujevac, Serbia
}

\begin{abstract}
Citation: Dimković DM. Memorial Architecture as the Symbol of Remembrance and Memories. SEE J Archit Des. 2016 June 10; 2016:10018. $h$ ttp://dx.doi.org/10.3889/seejad.2016.10018

Keywords: the culture of memory and remembrance; memorial architecture; spaces of memory; the Holocaust.

Correspondence: Danijela Miodrag Dimković. Faculty of Philology and Arts, University of Kragujevac, Kragujevac, Serbia. E-mail

Received: 31-Jan-2016; Revised: 23-Mar-2016; Accepted: 24-Mar2016; Published: 08-Jun-2016

Copyright: $\odot 2016$ Danijela Miodrag Dimković. This is an open-access article distributed under the terms of the Creative Commons Attribution License, which permits unrestricted use, distribution, and reproduction in any medium, provided the original author and source are credited.

Competing Interests: The author has declared that no competing interests exist.
\end{abstract}

\begin{abstract}
The aim of this study is to assess memory and remembrance in presenting important concepts that establish construction of space, architecture and memorialization of the Holocaust. Some examples of memorials as the visual arts in the evocations of the Holocaust indicate a change in the ideological image of memory and understanding approach to European heritage after the fall of the Berlin Wall. Architecturally, the memorial spaces created a system of allusions, coding of real space and new findings are part of the implementation and presentation of the architecture of memory.
\end{abstract}

\section{Introduction}

Ever since the ancient period there is a need to upgrade the memory by creating the bond between memory and space. The essence of such "art of memory" consists of imaginary contents of memory codified in compressed images associated with the formula of the structure of space with which the images are combined. Such an approach would represent the very beginning of the realization of complex "Architecture of Memory".

Aleida and Ian Assmann set a model of the communicational and cultural memory, partially highlighting the concept of the relationship of memory and space. Ian Assmann actually tried to explore three themes in cultural memory: remembrance, identity, and cultural continuity. Due to the difficulty of defining the concepts of memory and remembrance, there is a need for establishing relationships within these two categories. Based on Assmann's consideration cultural memory can be divided into mimetic memory, the memory of objects, communicative and cultural memory; of which the cultural memory is certainly the most complex and comprehensive concept.

Memories are often related to a material object that represents the semiotic signifier and the memory of that moment, which will not be repeated, becomes highlighted. Actually, the memory is mainly needed as an intermediary, signifier; in this study, it is a Memorial building, which is a document, evidence of the past, an archive that will be transmitted to future generations. If one accepts the importance of memory and remembrance within the mechanism of presenting memorial architecture, it is necessary to comprehend the approach to structuring the space of remembrance. According to Fernando Katroga, an archived memory stops existing as a memory, once separated from the only mediator able to revive it: the subject witness. In Assmann's study, such thinking is more linked to the communicative memory which is actually a memory that relates to the recent past, i.e. memories that people share with their contemporaries, generational memory, while the cultural memory comes to the distant past, which is reflected solely by means of symbols [1]. A communicative memory lasts as long as its subjects, while cultural memory lives longer than it's carriers.

In examining the theory of remembrance, it is necessary to point out the relationship between the individual and the collective memory of which Maurice Halbwach speaks. Collective memory belongs to the group defined by one or more common characteristics; 
actually, the group provides individuals as members of a particular group with collective memory. Assmann claims that existence of a certain event, person or place is essential for truth to became a memory and that an individual's memory, a feeling, is not a memory. Furthermore, places of remembrance are inseparable from the memory of time so it does not involve only physical space; actually, features of time are discovered in space and space is again measured by time. Bakhtin appointed us towards such considerations in the context of literature, which can certainly be applied in other art disciplines [2].

\section{Lieux De Memoire - Pierre Nora - Assmann}

As Pierre Nora points out, if a man was able to live in the memories, he would not have to create spaces in the name of these memories. Memory is a constant and current problem; one that connects us with the eternal present, while history only represents the past. Memory is absolute with its origin in the particular, spaces, gestures, performances and objects. Transforming memories are often based on psychological rather than historical principles, the subjective perception of different messages. In the framework of such aspirations spaces of remembrance are formed, which, according to Pierre Nora have three levels: physical, symbolic and functional. Their main purpose is to prevent forgetting and thus confirm their documentary function. These areas other than basic utilitarian have a much more complex concept of memory, based on which we try to give meaning to the world and step out there which lack of time and the historical chain. It can be considered that the contents of memory and space are inseparable because the memory cannot be developed without the presence of internal records that can be material, socially and symbolically alive. And if every memorial is a vestige of the past, its interpretation will produce a revival of memory only if its connotations are compared with what it's omitted, or hidden. Memorial symbolizes and actually simulates the presence of those who are "absent" on the basis of traces simultaneously hiding what they do not want to accept.

The act of remembrance shows that reconstruction of the past directly depends on the interest and interpreted present framework where politics, power and memory are closely related. The process of remembrance no longer means giving importance only to heroic deeds, but individual pain and suffering, as well as the revival of the crimes that were previously concealed and repressed.

Once every memory is formed, an overlap between the limits of communication and cultural memories is created. Creation of a memorial has a permanent form and content and thus the content becomes available for use by other institutions of the society. In this context, cultural memory has an abstract quality that is not limited to a couple of generations, distant from everyday life, yet retains a close connection with a particular social group and has a particular meaning in the construction and reconstruction of the past and the present. Such places are important for understanding the continuity that the history perseveres in its existence [3].

The term lieux de memory, introduced in theory by Pierre Nora, marks places of historical past. These places appear because it is more difficult, in fact, impossible to identify spontaneously the memory of the events for exact location. For this reason, institutions that will encourage the active memory and help the process of keeping the memories of historical facts are necessary. Through the implementation of a memorial, we prevent the process of forgetting, materialize intangible and connect past with the present.

Assmann highlights how the ability of memory rules imaginary places while cultural memories require a natural space. The opposite of the memorial is time, which can be the subject of a culture of memory. Pierre Nora accents places of remembrance, which are the carriers of cultural and historical importance. Memory and remembrance are certainly two very important mechanisms related to identification and presentation of a memorial and later for transfer testimonies of an event. Since there are plenty of carriers of the memories, we will here give the ones based on the model of memorial centers devoted to the representation of the Holocaust. In particular the case of the Holocaust Museum, Daniel Libeskind and the achievement of architect Peter Eisenman, Monument to the killed Jews in Berlin.

It is the space, which we occupy, move through, have constant access to and can reconstruct in our thoughts and imagination is the space we must take care of so that memory can survive [4]. Pierre Nora speaks of the memorial site, which belongs to the mythical nature, thinking of building, a monument, a book. Place of remembrance does not really stand out for its quality due to its material objectification, but due to its symbolic value. It is about permanent points of collective memory that exist for generations and is often incorporated into customs.

\section{Memorial Architecture as a Place Of Remembrance}

The Second World War took, among other things, over six million innocent victims, members of the Jewish people who found themselves targets of systematic extermination by Nazi Germany. Auschwitz, 
Treblinka, Mauthausen, Dachau, Majdanek, Jasenovac, Staro Sajmiste are just some of the mass graves of the innocent victims killed during the war. In addition to members of other enslaved peoples, the Jews constituted the most vulnerable ethnic community. It is necessary to have a constant reminder of these horrors, to know the facts, adopt them and think about terrible consequences of the Holocaust. Thus, raising the awareness of the need to preserve a dignified remembrance of the great human sacrifices that were a consequence of ideological and state concept of Nazi Germany and Fascist Italy.

Along with residential architecture, memorial architecture in the history of humanity represents the oldest form of architectural activity. An inevitable and often the most important part of the architecture of ancient civilizations, memorial architecture has built a material link between the earthly man and the divine or mythical cult. Throughout history, the memorial architecture gains new meanings and architectural features that are accompanied by social and cultural development. Accordingly, architects interest of for the new spatial and aesthetic considerations of the memorial objects grew. After big war suffering in the twentieth century, memorials became important places of national memory. The question is how to start remembering the horror? How to keep the memory of something we would prefer to forget? The Second World War was the most devastating military conflict in the history of humanity, immeasurable in terms of human losses and material damage. The experience and the fate of the prisoners in the concentration camps are particularly terrifying chapter, and dealing with the genocide of certain ethnic and racial groups in Europe, the heavy burden and obligation of each subsequent generation. Preserving the memory of the committed crimes through musicalization of the historical documents and artifacts, conservation of the spaces of horror, raising monumental complex or transfer of knowledge to the youngest generations during the educational process, is primarily a moral issue [5]. The Second World War crafted our sensitivity to the ethics of memory and dramatically changed our understanding of the mechanism of collective memory. Recovery of Historical Memory of World War II becomes particularly problematic today when we have fewer living witnesses of the epoch and increasing the time and emotional distance. Memorial complexes represent the media and ways of communication, the holders of the common remembrance, actually materialized memory. Increasingly, the public domain encounters and trusts in the ability of architects and fine artists to form a worthwhile representation of the past, inspired by the architectural complexes that will present and provide information about the scary part of history and also to provide hope in wiser and more cautious mankind in the future.

\section{Presentation of Memorial}

The complex representation of the Holocaust memorial further questions the realization of the object on the territory of Berlin, the capital of the nation which entails the horrors and consequences of the Holocaust. How a city like Berlin can call the Jewish people in its official history after the terrible suffering during the Second World War? The dilemma faced by a designer, an architect, is the complexity of the problem of reconciliation in a medium such as architecture. How to make a connection of the space, symbolism and significance? How can contemporary architecture be realized spatially independent of its content? How to present the relation between modern Germany's population and their own past in relation to the Holocaust at the same time? The realization of the Jewish Museum in Berlin was necessary as a memory and a special relationship between history, culture and the suffering that has been long suppressed. Berlin Jewish Museum generates a sense of disturbing return, the sudden revelation of previously buried past. Additional anxiety to authors of the Jewish Museum comes from memory and remembrance of the terribly complicated and harrowing process, of the individual as well as the society.

\section{Jewish Museum - Daniel Libeskind}

Architect Daniel Libeskind presents us the operation of the memories through architecture at the Holocaust museum and also the desire of Berlin and Germany for rebuilding and reconciliation between the two nations. The absence of the right angle, the realization of voids, empty spaces that invite a man to fill the void, to imagine it, to resolve it. The building is constructed around three axes (underground corridors): The axe of exile, the axe of the Holocaust and the axe of continuation. The first ends at the garden of the exile, the second at the tower of the Holocaust and the third at the installation of the Israeli sculptor Menashe Kadishmann - Fallen leaves. No matter how we interpret voids around which the object evolves, no one can escape the strong impression they impose.

By descending into the basement of the museum while moving constantly up and down along the axes of their captivity, along with sense of discomfort; visitor gets out into the garden in the shape of a square set on a hill, where olive trees grow in forty-nine concrete piers and the eye of the observer at the same time meets a warning sign saying you enter at your own risk. The exhibits that ensue are selected very carefully - letters, cups of tea, typewriter, photographs, sounds very innocent and then the 
content is again violently interrupted by empty space. Photography, as a representation of the figurative remembrance, automatically evokes the memory and affects processing in the form of memories.

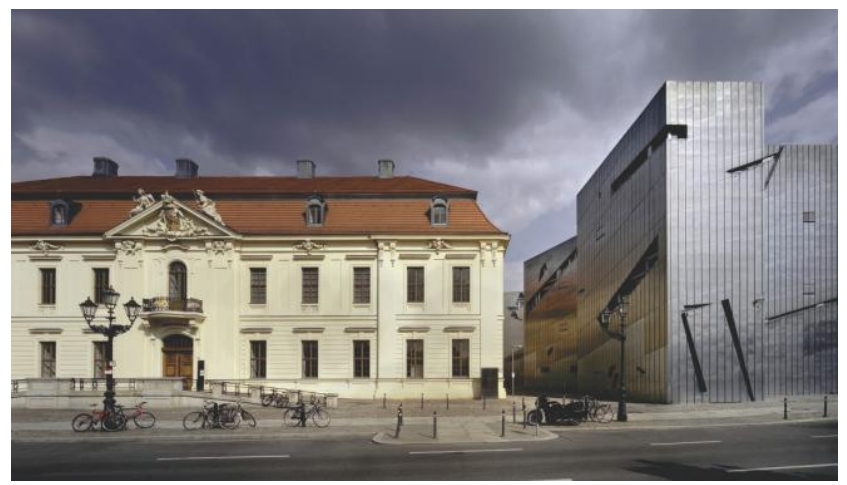

Figure 1: The Jewish Museum in Berlin, consists of two buildings, one of them is a new facility implemented by Daniel Libeskind

One of the questions Aleida Assmann deals with is why certain places or figures function as points of remembrance. She compares the "magic power of remembrance" with the "power of ancient symbols" or otherwise; explains the division of autobiographical memory, where one part remains with the carriers of that memory, and the second part is being written in the objects or places. Memory areas may be specific and true, but also can be only associative, given the reminders, signs, indications, and as such, they are the initiators of the memories. Memorials may be associated with historical places and their remains but can also occur in the form of monuments not connected to a specific historical location, being the sign of a particular group of victims and encouraging their recognition and acceptance within society [6].

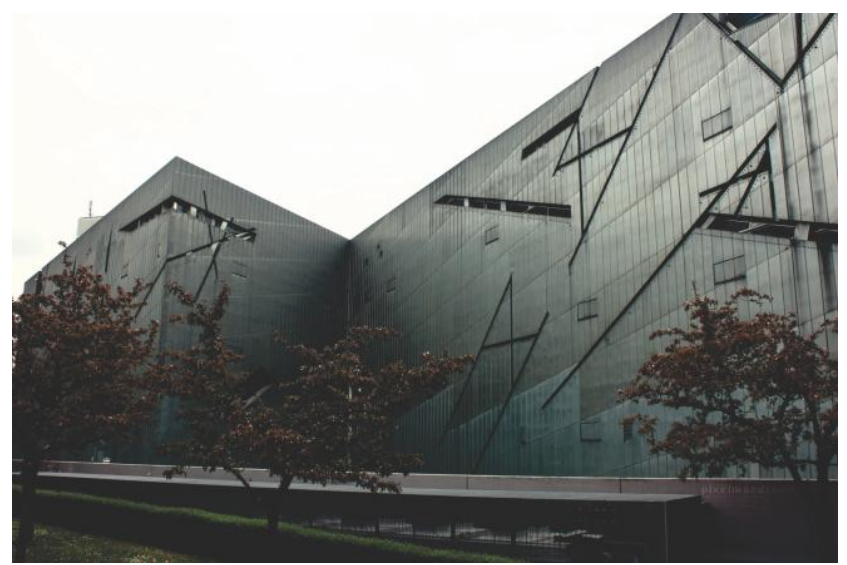

Figure 2: Daniel Libeskind, the Jewish Museum in Berlin, part of the facade of the museum

The tower of the Holocaust, at the end of the Holocaust axis, represents more than twenty meters high cell, without heating, illuminated by a single triangular window at the top, completely cut off from the rest of the space, with a door that closes with a loud snap lock additional underlying the feeling of narrowness and fear. Axis of continuation ends up trampling over different sizes of metal human faces, scattered on the floor. The setting itself speaks through exhibits about the life of Jews on the territory of Europe and Germany from the ancient period and if the architecture is enough to tell the story itself.

According to Aleida Assmann historic locations that have the capacity to make history tangible enable us to feel the magic of space [7]. If we do, we learn that something happened; we believe that the visit to this place will create the experience and understanding of the certain past that we can know and learn. Aleida Assman in her review of the premises and places of remembrance speaks and gives the example of Nazi concentration camps that are now converted into memorials and museums, but that does not say much about history; a visitor himself codes the space with his own expectations, knowledge and connections. Pierre Nora says the most authentic areas are the ones closest to the concept of memory. Such locations do not imply only the places where the crimes were committed, but also the places where the victims and occupiers stayed together at the same time. It can be a place where they adopted ideological political decisions. In these facilities, symbolic value is more significant than the historic one.

The Jewish Museum in Berlin is one of the largest Jewish museums in Europe; consists of two buildings, one of them is a new facility implemented by Libeskind. The permanent exhibition presents two millennia of Jewish history in Germany. The German Jewish history is documented in the collections, library, archives, and computer terminals. The museum was opened to the public in 2001. The first building of the Jewish Museum in Berlin was founded in 1933, but shortly afterward was closed in 1938; in 1988 Berlin government announced a design competition for the new museum, where Daniel Libeskind's radical solution was adopted; construction began in November 1992 and was completed in 1999.

Location of the memorial is not far from the Berlin Wall route, it is in a location that belonged to the West Berlin populated by the Jewish community. The only access to the building is via an underground passageway of the original museum building. All three mentioned tunnels, axis, intersect and may represent a link between three different memories of Jewish life in Germany. Each of the three spaces carries certain symbolism: the continuity with German history, emigration from Germany, and the Holocaust. The Jewish Museum of Daniel Libeskind clearly indicates the presence of historical concern. Formulated in this way, the building presents and becomes a problem of today and requires better and more specific determination. This formulation brings a certain precision, but still, there is a dilemma how to connect the remembrance and the historical context. As Andrew Benjamin recognizes, if the issue of Holocaust is linked to Nazi Germany, one cannot avoid the fact that other European nations did very little to stop the 
attempted genocide, or even actively contributed to its implementation [8]. It is impossible not to notice the concern for the present in the relationship between the memorial architecture and remembrance. It is impossible to recognize a memory and any type of implementation undertaken on its behalf so that memory exists according to its own destruction. Access to the realization of the project of the memorial complex must include a radically different approach to the way of thinking and a different architectural concept. Can architecture demonstrate the Holocaust? Every question brings us back to the present, which opens new fields and many more layers of meaning that are difficult to explain by scarce historical facts. Benjamin recognizes the difficulty that arises in examining the issues both in philosophy and architecture, and even though these two disciplines have diametrically different forms of presentation they will always return to the same issues. Mass murders in a certain area face the issues of remembrance, which is difficult to incorporate and adapt according to the principles of conventional theory. The specificity of the museum should be linked with the purpose of remembrance leaving aside the delicate and difficult question of architectural articulation. Libeskind explains, in a theoretical essay, that he wants to reclaim the trace of Berlin history in order to maintain the memory of the Holocaust and assign a new weight and value to exist historical context. Expansion of the existing museum building is not just a simple extension; the building is not only an added element but also a symbol of the amended loss [8]. This expansion applies to the issue of the comprehensive relationship with the whole and the formation of the inner complex. Benjamin questions the meaning of such extensions at this point, at the present time. What kind of relationship occurs between the extension and absence or of the expansion and destruction?

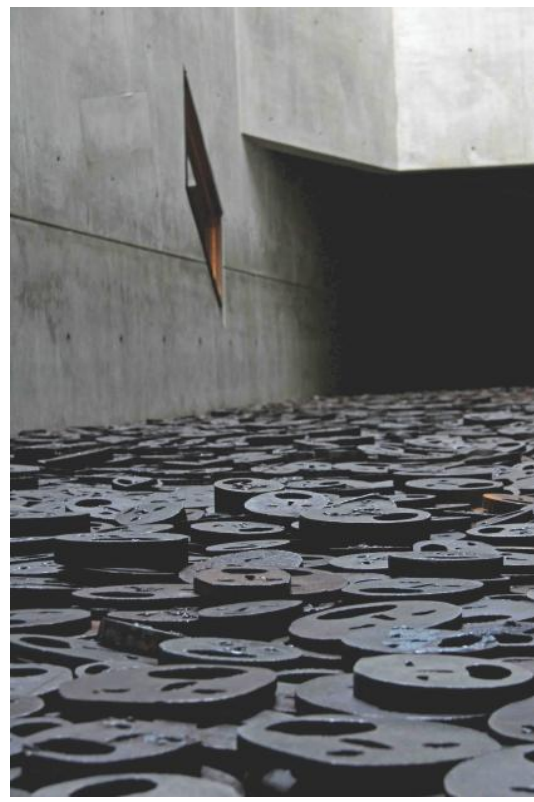

Figure 3: Daniel Libeskind, the Jewish Museum in Berlin, installation of the Israeli sculptor Menashe Kadishmann - Fallen leaves
This expansion questions architectural articulation. Benjamin believes that a certain time distance is necessary for consideration of Libeskind's architecture and its performance in the national problem of the Holocaust. As Libeskind used the term Architecture of hope for describing the memorial facility, in the future we can expect connecting hope with the memorial to require some form of architecture. He describes the relationship between the building and expansion of an empty space; in fact, the original idea of realization of the project was the construction of a museum around emptiness, a void that runs through architecture. Such gaps, among other things, can stand for a very small number of the Jewish population in Berlin in the present and thus make them invisible. Perhaps Libeskind's architecture is the opportunity for the contemporary Jewish culture in Berlin, to become visible and accessible. Empty space that pervades the building itself and enters into its structure, therefore, insists on the presence in any setting, which cannot exist without the emptiness. As Benjamin concludes, every visitor has to face the presence of absence in the symbolism of architectural solutions. This confrontation leaves the possibility of its transformation into an experience. The very structure of the building requires that the object is seen as a museum of forgiveness and reconciliation. Holocaust Memorial architecture today requires a reflection on Jewish identity equally as the new synagogues, schools, kindergartens. We can ask ourselves does it represent or symbolize? The postmodern theory emphasizes the functionality of space in architecture that now is not a prerequisite, but emphasizes the importance of the message and ideas. Is it even possible to go beyond the symbol where architecture is linked to the traumatic past?

\section{Memory of Jewish Victims - Peter Eisenman}

Another iconic example of Jewish architecture, in addition to Libeskind's achievement, is certainly a project of the architect Peter Eisenman - Memorial to the Murdered Jews of the Europe. According to the text of the project, Eisenman designed the blocks to produce discomfort. Confusing atmosphere introduces a system that lost touch with human reason in a certain point of time. And if the issue of the memorial is always controversial and a complex one, the need for it still exists. Eisenman's work includes educational material in the informative section of the museum; however, his greatest strength is the effect which was realized through abstraction of the pillars. Pillars resemble tombstones, yet it is not only tombstones, what they symbolize is the sense of loss and, as such, insist on the form of remembrance. It is this abstraction that Benjamin sees the quality and the power of different 
interpretations. How and what they represent is still an open question and part of that openness is actually a review of the possibilities for an appropriate image or content [9]. Just by asking questions and seeking adequate performances of the realized project, he defines this memorial as a quality solution. Eisenman claims that one of the goals of the memorial is opening discussions and debates which were completely shut down until recently. Memorial itself is rising from its specific context of the Holocaust and questions the problem of anti-Semitism and social responsibility today.

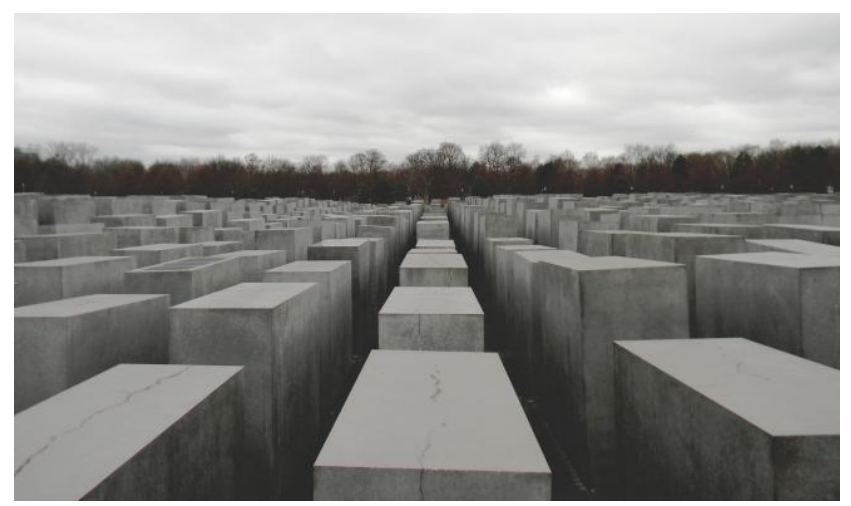

Figure 4: Peter Eisenman, Memorial to the Murdered Jews of the Europe

Creation of architecture of remembrance provides access to communities that can provide social support, unite people with similar experiences, help us understand the past, create and collect a variety of information, impressions, and knowledge to further under the events in the present. Eiseman's Information Center, which is located within the memorial, is a digital archive of documents, also mentioned by Aleida Assmann saying that the 80 years of the last century led to the digitization and essential media revolution, which was reflected in the memory of history and culture.

Thus in Germany, the "collective silence" came to an end and commemorative anniversaries and public debates, the Nazi past and the Holocaust have again become subjects of public awareness and public debates.

As Pierre Nora points out, by exploring the French places of remembrance, remembrance of groups do not hide the collective soul, nor objective spirit but a society with the media and institutions, signs and symbols. Museums, archives, festivals and monuments are memory places that always recombine physical, functional and symbolic aspects of the past and regulate the presence of the past in the present [9]. To re-find the past, we reconstruct it based on different sources and monuments, and that is the purpose of memory as constructed remembrance.

We conclude that despite all the complexity of the architecture of remembrance, it maintained the "culture of the technique of remembering" since ancient times. However, another conclusion is imposed - there is a great need theoretical consideration in architects work.

It was not until the last twenty years that more emphasis has been dedicated to architectural theory, as an important aspect of architectural literacy architectural pedagogy. The theoretical analysis would enable monitoring of the development of an architectural theory that takes place over time. This would open the possibility of integration with political and philosophical theories. Consideration of the introduction of the theory of the architecture provides the basis for such a broad and complex thinking. The most important change is that the outcome of this thinking is definitely the answer to the needs of architects to create a connection between meaning and forms. Daniel Libeskind and Peter Einsman belong to modern architects actively engaged in considering theoretical problems. Certainly, it was a theoretical aspect that served as the base for the realization of these memorials, which should be equally thoroughly applied in the case of the other memorial complex.

\section{References}

1. Asman J. Kultura pamćenja. Beograd: Prosveta, 2011.

2. Bakhtin M. The Dialogic Imagination: Four Essays. University of Texas Press Slavic Series, 1989.

3. Between Memory and History. Les Lieux de Memoire, Pierre Nora,

www.history.uesb.edu/faculty/marcuse/classes/201/articles/89NoraL ieuxIntoRepresentations.pdf [Accessed 21st January 2014]

4. Albvaš M. Kolektivno i istorijsko pamćenje. Beograd: Reč, 1999.

5. Butković Mićin L. Arhitektura sjećanja.

http://www.zarez.hr/clanci/arhitektura-sjecanja

6. Martinoli A. Staro Sajmište - istorijsko sećanje i virtuelno promišljanje budućnosti. Tekstovi sećanja: filmski,medijski i digitalni, "Identitet i sećanje: transkulturalni tekstovi dramskih umetnosti I medija, Ministarstvo prosvete i nauke Republike Srbije, 1989-2014.

7. Asman A. Duga senka prošlosti. Beograd: Biblioteka 20 vek, 2011.

8. Benjamin A. Present Hope - Philosophy, Architecture, Judaism. Routledge, 1997.

9. Benjamin A. Writing Art and Architecture. re.press, Melbourne, 2010. 